\title{
Nitrification of ammonium-rich sanitary landfill leachate
}

\begin{abstract}
The nitrification of ammonium-rich wastewater is considered challenging due to the substrate inhibition particularly in the form of free ammonia (FA) and free nitrous acid (FNA) in ammonia-oxidizing bacteria (AOB) and nitrite-oxidizing bacteria (NOB). The feasibility of the nitrifying activated sludge system to completely nitrify synthetic stabilized landfill leachate with concentration of $1452 \mathrm{mg} / \mathrm{L}$ was tested in this study. The process started with $0.4 \mathrm{~kg} / \mathrm{m} 3 /$ day of nitrogen loading rate (NLR) in a fed-batch mode to avoid any accumulation of the FA and FNA in the system followed by increasing the nitrogen loading rate (NLR) gradually. Complete nitrification was achieved with a very high ammonium removal percentage (100\%). The maximum specific and volumetric nitrification rate obtained were $0.49 \mathrm{~g} / \mathrm{g} \mathrm{VSS} /$ day and $3.0 \mathrm{~kg} / \mathrm{m} 3 /$ day, respectively which were higher than those reported previously for ammonium-rich removal using activated sludge system. The nitrifying sludge exhibited good settling characteristics of up to $36 \mathrm{~mL} / \mathrm{g}$ VSS and a long SRT of more than 53 days which contributed to the success of the nitrification process. The coexistence and syntrophic association of the AOB and NOB was observed by using Fluorescence in situ hybridization (FISH) technique which supported the results on complete nitrification obtained in the system. These findings would be of prominent importance for further treatment of actual sanitary landfill leachate.
\end{abstract}

